\title{
Agnieszka Sell
}

Uniwersytet im. Adama Mickiewicza w Poznaniu

Wydział Filologii Polskiej i Klasycznej

\section{Czyj to rewolwer? Historia fragmentu z pamiętnika Edvarda Muncha}

5 czerwca 1901 roku odnaleziono w Tyflisie dwie ofiary rewolweru zastrzeloną Dagny Juel Przybyszewską i jej zabójcę, zmarłego śmiercią samobójczą Władysława Emeryka. Młodopolska Aspazja odeszła w dalekim kraju, za zamkniętymi drzwiami hotelowego pokoju. „Dlaczego o tej pani mówią, że zjawia się jak Makryna?"1 - pytał Jarosław Iwaszkiewicz. Legendy rosną szybciej karmione literaturą. Postać wieszczacej śmierć Makryny przyniósł Śnieg Stanisława Przybyszewskiego, a Stanisław Korab-Brzozowski - nieszczęśliwie zakochany w Dagny Juel - dołączył do „łańcucha lwowskiego", ostatecznie poświadczając w oczach współczesnych związek tych dwóch kobiet - prawdziwej i zmyślonej.

Młodopolskie mity pozostawały poza kontrolą nawet tak wytrawnych autokreatorów, jak Władysław Reymont czy Stanisław Przybyszewski. Jak bowiem zauważył Józef Dynak:

O autorze Requiem aeternam mówili i pisali prawie wszyscy: znawcy literatury i ignoranci, ludzie, którzy zetknęli się z nim osobiście lub tylko słyszeli plotki, przyjaciele i wrogowie. Mało kto - zarówno spośród najznamienitszych piór epoki, jak i zwykłych pismaków - nie zabierał głosu na jego temat. Nic dziwnego, że artysta skazany był na sądy przypadkowych krytyków, pamiętnikarzy i pseudoliteratów, kierujących się osobistymi sympatiami i animozjami².

Dla autora De profundis podobno żadna plotka nie była zbyt skandaliczna i wszystkie cieszyły go jednakowo ${ }^{3}$, sam też starał się podsycać niesamowitymi opowieściami zainteresowanie swoją osobą. Jego żona z kolei nie wypowiadała się na swój temat prawie wcale, nie ujawniała żadnych sekretów. Może - jak pisze Ewa K. Kossak - „uznała, o co dotąd się ją

${ }^{1}$ E. K. Kossak, Dagny Przybyszewska. Zbłąkana gwiazda, Warszawa 1973, s. 341.

${ }^{2}$ J. Dynak, Przybyszewski: dzieje legendy i autolegendy, Wrocław 1994, s. 29.

${ }^{3}$ L. Krzywicki, Stanistaw Przybyszewski, [w:] Wspomnienia, t. 2, Warszawa 1958, S. 441. 
podejrzewa, że to bardziej interesujące, jeśli jest się spowitym w mgłę tajemnicy i niedopowiedzeń" . Pozór był częścią tego świata i tylko śmierć - rzeczywista, nie literacka - potrafiła przypomnieć, że między życiem a gawędą o życiu nie można postawić znaku równości. Minuta ciszy mijała, opowieść trwała dalej, a prawda stawała się źródłem nowych, znakomitszych nawet fantasmagorii. Jeszcze w czerwcu 1901 roku, Józef Rabski napisał:

W orgii dekadenckiej grzmią nagle dwa strzały: on ginie i ona. Za powagą życia idzie powaga śmierci. Nadczłowiek kocha się bez dramatu, a człowiek pada ofiarą. Nadczłowiek byłby romans napisał, człowiek sięgnął po rewolwer ${ }^{5}$.

Podczas gdy Przybyszewski wyrażał w Na drogach duszy swoje pragnienie, „aby coś we mnie wzbudziło uczucie, które mnie do obłędu doprowadzić może, [...] aby mnie coś mogło popchnąć na drogę najwyuzdańszej rozpusty, dać mi nóż lub rewolwer w rękę”, Władysław Emeryk, „zwykły człowiek", sięgnął po broń. Była to broń obrosła legendą nie mniejszą, niż kobieta, którą postanowił z niej zastrzelić. Spadkowi po Stanisławie Korab-Brzozowskim, rewolwerowi, który stał się narzędziem jego samobójczej śmierci, temu wędrownemu przekazicielowi złych wieści, dalece bardziej niż Dagny, należało się w tej historii imię Makryny.

Eli Greve zauważyła, że „w czasach bohemy załadowany rewolwer przynależał do stałej dekoracji, a samobójstwo było uznanym sposobem rozwiązywania dramatycznego konfliktu"7, nic zatem dziwnego, że wypadki celowego, a częściej nawet przypadkowego postrzelenia, nie należały do rzadkości, zaś otoczony tragicznym nimbem przedmiot stawał się bohaterem szeregu utworów literackich. Jednym $\mathrm{z}$ nich jest Requiem aeternam Stanisława Przybyszewskiego:

Stałem w rogu pokoju z rewolwerem przy skroni i dyszałem.

Nie rób tego, nie rób tego! nie, nie! Na Boga nie! tylko tego nie!

Odetchnąłem głęboko:

Boże, jakżeż można się tak przerazić, to przecież nie ja, to czarny paletot, co wisiał w rogu, na ścianie ${ }^{8}$.

${ }^{4}$ E. K. Kossak, Dagny Przybyszewska..., s. 106.

${ }^{5}$ W. Rabski, Nadludzie bez maski, „Kurier Warszawski” 1901, nr 171, s. 2. Za wskazanie tego artykułu dziękuję Profesorowi Radosławowi Okulicz-Kozarynowi.

${ }^{6}$ S. Przybyszewski, Na drogach duszy, Kraków 1900, s. 37.

7 E. Greve, Edvard Munch. Liv og verk i lys av tresnittene, Oslo 1963, s. 23 (przekład własny - A. S. Dalsze cytaty z książek nietłumaczonych na język polski, o ile nie podano inaczej, przytaczam w przekładzie własnym). Fragment tego zdania przywołuje w swojej książce A. Næss, Munch. Biografia, przel. I. Zimnicka, Warszawa 2007, s. 244.

${ }^{8}$ S. Przybyszewski, Requiem aeternam, [w:] tegoż, Wybór pism, oprac. R. Taborski, Wrocław 1966, s. 74, cyt. za: P. Dybel, Pogrzeb Edypa, [w:] tegoż, Urwane ścieżki. Przybyszewski - Freud - Lacan, Kraków 2000, s. 54. 
W książce Urwane ścieżki. Przybyszewski - Freud - Lacan Paweł Dybel przytoczył powyższy fragment, poprzedzając go jeszcze dwoma innymi z tego samego utworu:

W ponurym świetle jarzących się gromnic leżał w trumnie trup kobiecy.

Gromnice dogorywały; światło było niespokojne, pryszczało i drżało, i rzucało dziwne cienie na twarz kobiety.

Przykucnąłem, a w rdzeniach włosów poczułem kłucie jak od szpilek na całej głowie.

Było coś w jej twarzy, co mnie przyciągało i do ziemi przykuwało. Na twarzy, grą światła pocentkowanej jak skóra tygrysia, ujrzałem nagle straszną wizję: szeroko rozdziawiona paszczęka grzechotnika, z dziwnie latającym, długim językiem. Słyszałem dokładnie jadowity syk - a może ja sam syczałem.

$[\ldots]$

Patrzała na mnie wylęknionymi oczyma i przytuliła się do mnie.

- Kochasz mnie - pytała i przesuwała lekko swą piękną rękę po mej głowie.

- Może być; nie wiem.

Odsunąłem z wolna moje krzesełko.

Patrzała na mnie z tym samym przerażeniem i przestrachem, z jakim patrzał na mnie mój stary pies, gdym go musiał zabić9 .

Poświęcony pisarstwu Przybyszewskiego szkic Pogrzeb Edypa, przynosi niezwykle intrygujące spostrzeżenie, dotyczące podobieństwa scen z Requiem aeternam do pewnego epizodu znanego z biografii Edvarda Muncha. Paweł Dybel cytuje, za Slavojem Žižkiem, krótką opowieść o tragicznie zakończonym związku norweskiego malarza:

W 1893 roku Munch był zakochany w pięknej córce handlarza win z Oslo. Dziewczyna lgnęła od niego, on jednak w obawie o swoją artystyczną pracę nie chciał się z nią wiązać, dlatego ją rzucił. Ale pewnej burzliwej nocy przybył do niego posłaniec mówiąc, że młoda kobieta jest na łożu śmierci i że chce odbyć z nim ostatnią rozmowę. Wieść ta głęboko poruszyła Muncha, który natychmiast udał się do domu ukochanej, gdzie zastał ją leżącą na łóżku pomiędzy dwiema palącymi się świecami. Kiedy jednak zbliżył się do łóżka, kobieta wstała i zaczęła się śmiać: cała zaaranżowana przez nią scena okazała się jedynie maskaradą. Munch obrócił się na pięcie z zamiarem odejścia: w tym samym momencie kobieta zagroziła, że jeśli ją opuści, to ona się zastrzeli i wyciągnąwszy rewolwer skierowała go ku swoim piersiom. Gdy Munch się pochylił, starając się odebrać jej broń, głęboko przekonany, że również i ta groźba stanowi element maskarady, rewolwer wystrzelił raniąc go w dłoń... ${ }^{10}$

„Niemiecko-skandynawsko-polską kolonię"11, która spotykała się w berlińskim „Czarnym Prosiaku”, lączyły skomplikowane relacje i głębokie artystyczne zależności, a bardziej znani twórcy wspierali niekiedy

${ }^{9}$ S. Przybyszewski, Requiem aeternam, s. 64-65, cyt. za: P. Dybel, Pogrzeb Edypa..., S. $53-54$.

${ }^{10}$ P. Dybel, Pogrzeb Edypa..., s. 53.

${ }^{11}$ W. Rabski, Nadludzie bez maski..., s. 1. 
karierę tych nowych i mniej rozpoznawalnych. August Strindberg - przed animozjami związanymi z osobą Dagny Juel - nazwał Przybyszewskiego „der geniale Pole”, Przybyszewski z kolei w 1894 roku wydrukował we „Freie Bühne” esej Psychischer Naturalismus, w którym wyraził zachwyt niedocenianym malarstwem Edvarda Muncha. „Jestem przerażony, że jakiś człowiek mnie w najtajniejszych twórczych chwilach podsłuchuje - ale i ja ciebie podsłuchałem"12 - tymi słowami miał, według Przybyszewskiego, zwrócić się do niego po publikacji norweski malarz. Podobieństwo wskazanych przez Pawła Dybla fragmentów sugeruje, że owo podsłuchiwanie istotnie mogło mieć miejsce. Autor Pogrzebu Edypa zwraca uwagę na pewne wspólne doświadczenie, będące udziałem obu artystów - związek z Dagny.

Jeśli przypomnimy, że owa córka handlarza win z Oslo, z którą romans zakończył się tak niefortunnie dla Muncha, to Dagny, późniejsza kochanka (a jeszcze później żona) Przybyszewskiego [...], zrozumiałe staje się uderzające „strukturalne” podobieństwo obu przytoczonych tu scen: rzeczywistej i wyimaginowanej. Przybyszewski musiał być świadkiem podobnie histerycznych napadów, inscenizowanych przez Dagny, aby następnie „w przeniesieniu”, w przetworzonej przez własną wyobraźnię postaci, powtarzać je na kartach własnej esejo-noweli ${ }^{13}$.

Edvard Munch nie jest bohaterem szkicu Pogrzeb Edypa, są nimi Stanisław Przybyszewski i jego twórczość, toteż fragment dotyczący postrzału z rewolweru, którego konsekwencją było dożywotnie okaleczenie dłoni norweskiego malarza, potraktowany został tu jedynie przyczynkowo. Punktem wyjścia dla rozważań Pawła Dybla były poczynione przez Slavoja Žižka spostrzeżenia dotyczące kobiecej histerii - pisarstwo Przybyszewskiego z okresu powstania Totenmesse nosi, według interpretacji z Pogrzebu Edypa, znamiona histeryczności. Rozpoznana jako inspiracja dla utworu literackiego i osadzona w nowym, niezaprzeczalnie fascynującym kontekście, historia z życia Muncha została od tego życia de facto oderwana. Stwierdzenie to wydaje się banalne, a skutki owego oderwania - na pierwszy rzut oka - zupełnie nieszkodliwe. Nie zapominajmy jednak, że mowa o epoce „ubranej w mgły teatralne” 14 .

Wśród niedatowanych notatek Edvarda Muncha znajduje się zdanie: „prawda leży pomiędzy dwoma kłamstwami”, które - pozbawione kontekstu i zawieszone w próżni - prowokuje. Można oczywiście poszukiwać wśród zapisków malarza powodu poczynienia takiej konstatacji, jednakże wobec ogromu zmyśleń, przeplatających w życiorysach modernistycznych

\footnotetext{
${ }^{12}$ S. Przybyszewski, Moi wspótcześni. Wśród obcych, Warszawa 1926, s. 195.

${ }^{13}$ P. Dybel, Pogrzeb Edypa..., s. 54.

${ }^{14}$ W. Rabski, Nadludzie bez maski..., s. 2.
} 
artystów prawdy i półprawdy, doskonale obywa się ona bez konkretnego inspiratora. Atle Næss uczynił ją mottem dla napisanej przez siebie biografii Muncha ${ }^{15}$, wskazując tym samym na przynależność historii życia norweskiego malarza do kręgu tych silnie zmistyfikowanych i trudnych do odtworzenia, jednakże pełne brzmienie zyskują te słowa dopiero w towarzystwie drugiego cytatu, pochodzącego z dziennika kuzyna artysty, Ludviga Ravensberga: „Munch miał więcej rozumu niż wszyscy jego biografowie, a ta straszliwa powierzchowność, będąca ogłupiającą dżumą naszych czasów, całkiem wykrzywiła jego postać"16. Ton wypowiedzi jest ostry, jednak przywołując ją zaraz obok notatki Muncha, Atle Næss wskazuje na problem, z jakim mierzy się jego biograf lub szerzej - osoba, w której tekście Munch jest w jakikolwiek sposób obecny: nawet taki epizod, który bez trudu pozwala się streścić w jednym akapicie, wymaga weryfikacji.

Dotyczący Muncha cytat zamieszczony w Pogrzebie Edypa pochodzi z książki The Metastases of Enjoyment Slavoja Žižka ${ }^{17}$, ale można go znaleźć i w innych tekstach napisanych przez tego autora ${ }^{18}$. Do nich trafił on, w formie parafrazy, z biografii Edvarda Muncha autorstwa Josefa Paula Hodina $^{19}$. W kolejnej książce, w której Hodin przywołuje postać norweskiego malarza - późniejszej od Edvard Munch: Nordens genius o osiem lat The Dilemma of Being Modern - pojawia się kilka elementów wzbogacających opowieść o nocy, w czasie której padł strzał z rewolweru:

Pewnej burzliwej nocy statek przypłynął z Larkollen do Åsgårdstrand z przyjaciółmi Muncha na pokładzie, był z nimi znany krytyk artystyczny S. Bödtker ${ }^{20}$. Przybyli, aby sprowadzić Muncha. Powiedzieli, że kobieta była na progu śmierci i chciała mówić z nim po raz ostatni. Munch podążył za nimi. Owinięta całunem kobieta leżała na katafalku, po obu stronach mając zapalone świece. Gdy Munch do niej podszedł, wstała i powiedziała: „wiedziałam, że przyjdziesz”. Munch był zszokowany tym podstępem. Odwrócił się, by ponownie ją opuścić, ale ona wzięła rewolwer, skierowała go w stronę swojej piersi i zagroziła, że się zastrzeli. Aby ją uspokoić, Munch położył swoją dłoń na lufie broni. Ta wypaliła, raniąc jego środkowy palec, który został okaleczony na zawsze ${ }^{21}$.

Anonimowego posłańca zastąpili w tej wersji przyjaciele Muncha, pojawiło się nawet nazwisko Sigurda Bødtkera, który miał być wówczas na

${ }^{15}$ A. Næss, Munch..., s. 5.

${ }^{16}$ Tamże.

${ }^{17}$ S. Žižek, Metastases of Enjoyment, London 2005, s. 150. Polski przekład: Metastazy rozkoszy, przeł. M. J. Mosakowski, Warszawa 2013.

${ }^{18}$ S. Žižek, Interrogating the Real, London 2005, s. 49; S. Žižek, M. Dolar, Opera’s Second Death, New York 2002, s. 192.

${ }^{19}$ J. P. Hodin, Edvard Munch, London 1972, s. 88-89 (angielski przekład Edvard Munch: Nordens genius).

${ }^{20}$ Taki zapis nazwiska Sigurda Bødtkera stosuje Josef Paul Hodin.

${ }^{21}$ J. P. Hodin, The Dilemma of Being Modern, London 1956, s. 27. 
pokładzie. Zrozumiałe staje się, po sprawdzeniu położenia dwóch miejscowości na mapie, dlaczego malarz zmuszony był odbyć podróż statkiem, lub - jak w wersji podanej przez Žižka - żaglówką. Paweł Dybel pominął problem środka transportu, czym niewątpliwie odebrał sytuacji sporo dramatyzmu. Pod dostatkiem jest go z kolei w książce Hodina - łóżko zastąpił katafalk, a ciało kobiety pokrył całun. Takie - jak się zdaje - nieznaczące różnice, zaobserwować można nie tylko po porównaniu prac Hodina, Žižka i Dybla - historia „burzliwej nocy” pojawia się w różnych kontekstach w szeregu innych prac i niezmiernie często nosi znamiona drobnych przeróbek lub przeinaczeń. Pozostaje zastanowić się nad tym, czym różni się ta powtarzana wielokrotnie opowieść od prawdziwej wersji wypadków i czy owa prawdziwa wersja w ogóle istnieje.

Pierwszym i - jak się zdaje - kluczowym pytaniem, które należy zadać, jest to o tożsamość występującej w opowieści kobiety. Według Pawła Dybla to Dagny - takie rozpoznanie pasuje do dalszej części wywodu badacza, jednakże nie znajduje pokrycia w rzeczywistości. Jak pisze biografka i znawczyni twórczości Dagny Juel Przybyszewskiej, Aleksandra Sawicka:

Plotką ugruntowaną w powszechnej świadomości jest przede wszystkim informacja, jakoby Dagny Juel i jej siostry były przyjaciółkami Muncha z czasów dzieciństwa. [...] Powstała [...] na skutek skojarzenia przez badaczy zawodu ojca Dagny i ojca Muncha, będących lekarzami na terenie tej samej prowincji. [...] Obaj lekarze nigdy nie poznali się osobiście ${ }^{22}$.

Sawicka wyprowadza z materiału źródłowego (przede wszystkim listów) wniosek, iż początki znajomości Przybyszewskiej i Muncha nie sięgają dzieciństwa. Wiele wskazuje też na to, że to nie malarz był osobą, która wprowadziła Dagny do towarzystwa bywającego w szynku „Pod Czarnym Prosiakiem”23. Ich pierwsze spotkanie należy datować na lato 1892 roku, kiedy to powstał obraz Muzykujace siostry ${ }^{24}$.

Obecnie mają tu miejsce dwie wystawy malarskie, Muncha i duńskiego malarza Willemsena. Munch [...] wystawia zabawny portret panien Juel, może go Pani widziała, kiedy Pani tu była. Ragnhild śpiewa, Dagny zaś akompaniuje ${ }^{25}$.

Warto w tym miejscu przywołać datę, jaką Stanisław Przybyszewski umieścił pod Totenmesse. Napis pod utworem głosi „Pfingsten 93”.

${ }^{22}$ A. Sawicka, Dagny Juel Przybyszewska. Fakty i legendy, Gdańsk 2006, s. 155.

${ }^{23}$ Zob. tamże, s. 159.

${ }^{24}$ Zgodni są w tej kwestii m.in. Aleksandra Sawicka, Atle Næss oraz Frank Høifødt, autor książki Kunsten, kvinnen og en ladd revolver. Edvard Munch anno 19oo, Oslo 2010.

${ }^{25}$ List Margarete Dons do Randi Blehr, pisany jesienią 1892 roku z Kristianii, cyt. za: A. Sawicka, Dagny Juel Przybyszewska..., s. 157. 
Zielone świątki oznaczają maj lub czerwiec, a zatem poznanie dwójki Norwegów i powstanie utworu dzielił niecały rok lub nawet pół roku, jeśli weźmiemy pod uwagę zdanie „w 1893 roku Munch był zakochany w pięknej córce handlarza win z Oslo". Ta informacja nie wyklucza oczywiście tezy o zainspirowaniu się przez Przybyszewskiego doświadczeniami Muncha. W końcu, jak twierdził pisarz, „dopiero w czerwcu 94 napisałem pod wpływem bardzo silnych wrażeń Totenmesse" ${ }^{26}$. W przywołanym powyżej cytacie z książki Aleksandry Sawickiej pojawia się jednak informacja znacznie bardziej ważka, a dotycząca zawodu ojca Dagny. Ojcowie Muncha i sióstr Juell ${ }^{27}$ byli lekarzami, świadczy to zatem dobitnie o tym, że „córka handlarza win z Oslo” to nie Dagny. „Młodopolska Aspazja” pochodziła zresztą z miejscowości Kongsvinger, nie ze stolicy Norwegii. Wszystkie zebrane informacje wskazują na zupełnie inną osobę:

[...] Wyjazdy do Kristianii zaowocowały nie tylko kupnem domu. Podczas jednej z wizyt w stolicy [Munch] poznał Mathilde Larsen, której [...] nie nazywano nigdy prawdziwym imieniem, tylko spieszczeniem „Tulla”. Prawdopodobnie poznali się 10 sierpnia 1898 roku, w każdym razie tę datę Tulla wymienia rok później w jednym z listów. Możliwe, że bawiła się wtedy w mieście - tego dnia bowiem kończyła dwadzieścia dziewięć lat. Mathilde Larsen była córką najsłynniejszego kupca winnego w Kristianii ${ }^{28}$.

To Mathilde „Tulla” Larsen była z Munchem owego wieczoru, gdy wystrzelił rewolwer, ale - jak widać - wypadki te miały miejsce po 1898 roku, nie zaś w roku 1893, jak chcieliby tego przywoływani na początku artykułu badacze ${ }^{29}$. Cytowane w Pogrzebie Edypa fragmenty Totenmesse nie mogły zatem powstać z inspiracji wydarzeniami z życia Muncha. Niemniej jednak, jak słusznie wskazuje Paweł Dybel, podobieństwo między opisem nocy, w czasie której Munch został postrzelony, a scenami z Requiem aeternam jest uderzające i powinno dać do myślenia. We wstępie do pamiętnika Edvarda Muncha J. Gill Holland pisze:

Ważnym jest, by pamiętać, że Munch, opowiadając swoje miłosne historie, nie wyłączał z nich elementu imaginacyjnego. Jego słowa zabierają nas do głębi jego psychiki. Do jakich wniosków może prowadzić lektura stron z dzienników Muncha? To oczywiste, że ich frag-

${ }^{26}$ Błąd Stanisława Przybyszewskiego w datowaniu. Jak już wcześniej wspomniano, Totenmesse napisał w 1893 roku. S. Helsztyński, Najwcześniejsza nieznana autobiografia St. Przybyszewskiego, „Wici” 1935, nr 5.

${ }^{27}$ Gudrun, Ragnhild i Dagny uprościły pisownię swojego nazwiska. Dagny zrobiła to najprawdopodobniej w 1890 roku. Por. A. Sawicka, Dagny Juel Przybyszewska..., s. 25-26.

${ }^{28}$ A. Næss, Munch..., s. 188.

${ }^{29}$ Hodin nie podaje w The Dilemma of Being Modern roku, pisze o „drugim najbardziej twórczym okresie”, który miał miejsce w czasie, gdy Munch mieszkał w Åsgårdstrand. Zob. J. P. Hodin, The Dilemma..., s. 27. 
menty są fikcyjne. [...] Jego dzienniki były przez dziesięciolecia laboratorium, w którym zapisywał sceny, wizje, historie $[\ldots]^{30}$.

Lektura pamiętnika Muncha potwierdza spostrzeżenia Hollanda - notatki te przypominają utwór literacki. Mają dwóch bohaterów - Muncha, który pisze o sobie ,ja”, i Brandta, literackie alter ego, wraz z którym wkracza do zapisków narracja trzecioosobowa. Brandt występuje w tych samych epizodach, w których pojawia się Fru L., rozpoznana przez badaczy jako Tulla Larsen ${ }^{31}$ i to on jest osobą, która płynie do umierającej kobiety. Na pokładzie rozmawia z Fr. D.:

- Zastanawiam się czy nie żyje - Będziemy wiedzieli, gdy podpłyniemy bliżej, czy okiennice będą zamknięte - leżała w ciemnościach, kiedy wychodziłam - Będzie martwa, kiedy dotrzemy? - Brandt widział ją leżącą - białą - nieruchomą - sztywną - Zasmuconą przez niego śmiertelnie - Nie mógł jej pocieszyć - przywrócić życia tym zesztywniałym kształtom i strach ścisnął jego serce - Jak długo to trwało - łódź wciąż przecinała wodę ze wściekłą prędkością̧2.

Nie ma zgody w kwestii tożsamości Fr. D., choć zagadka nie wydaje się trudna do rozwiązania. Mary Kay Norseng twierdzi wprawdzie, że to Dagny, jednakże w pamiętniku inicjały są konsekwentnie wywodzone od nazwisk, a obok Fru i Fr. D. pojawia się też Fr. Dahl. Według zapisków Muncha, Cecilie Dahl - malarka i przyjaciółka Tulli - była zatem na pokładzie łodzi, którą płynął do niedoszłej samobójczyni. Z nocy z 22 na 23 sierpnia 1902 roku pochodzi list, który artysta otrzymał od Dahl:

Dziś wieczorem T. opróżniła butelkę morfiny. Kiedy szłam do łóżka, usłyszałam jej westchnienia. Poszłam do niej, powiedziała mi co zrobiła. Jej puls prawie zanikł. Napoiłam ją sześcioma filiżankami mocnej kawy. Na szczęście zjawiłam się w porę. Ona chce umrzeć. Jest przez ciebie w rozpaczy. Tylko ty możesz ją uratować. Jest teraz wpół do piątej. Jeśli chcesz z nią rozmawiać, musisz znaleźć łódź. Koło jej łóżka widziałam dwie puste fiolki morfiny ${ }^{33}$.

Znalazła się zatem odpowiedź na pytanie o rok, w którym rozegrały się wydarzenia „burzliwej nocy”. Frank Høifødt notuje także, za pamiętnikiem

${ }^{30}$ J. G. Holland, Introduction [w:] The Private Journals of Edvard Munch, ed. and trans. J. G. Holland, Madison 2004, s. 4.

${ }^{31}$ S. Prideaux, Edvard Munch. Behind the Scream, Yale, 2007, s. 187; M. K. Norseng, Dagny Juel Przybyszewska: the woman and myth, Seattle-London 1991, s. 179.

${ }^{32}$ The Private Journals..., s. 160-161. Fragment przytoczonego tu cytatu por. A. Næss, Munch..., s. 242.

${ }^{33}$ List Cecilie Dahl do Muncha z 23 sierpnia 1902 roku, cyt. za: S. Prideaux, Edvard Munch..., s. 221-222. Podany fragment listu nie ma w książkach Prideaux i Næssa tego samego brzmienia. Por. A. Næss, Munch..., s. 241. 
Muncha, informację o telegramie od Sigurda Bødtkera, który - przypomnijmy - miał w wersji z książki Hodina znajdować się na pokładzie statku płynącego z Larkollen. Materiały źródłowe potwierdzają, że Munch spotkał się z Bødtkerem i Dahl (w pamiętniku jest jeszcze informacja o „małej żonie" krytyka ${ }^{34}$, o czym biografowie nie wspominają) i razem z nimi wyruszył do Tulli, ale wspólną podróż odbywali oni dopiero z Drøbak wcześniejszy odcinek Munch przepłynął samotnie. Interesujące jest także to, że - według danych Norweskiego Instytutu Meteorologicznego, które przywołuje Atle Næss - 24 sierpnia można było liczyć się z co najwyżej „świeżą bryzą"35, a zatem określenie „burzliwa noc” wydaje się stosowne jedynie o tyle, o ile jest używane w znaczeniu metaforycznym. Wskazuje jednak, w kontekście pamiętnika Muncha, na coś jeszcze.

Artysta zastosował szereg rozwiązań, które potęgują wrażenie, że jego pamiętnik jest utworem literatury pięknej, nie zaś użytkowej. Zapiski malarza ułożone są w strofy, część z nich - jak już zostało wspomniane - przyjmuje za bohatera wypowiadającego się w pierwszej osobie Muncha lub też Brandta wraz z narracją trzecioosobową. Część z nich jest też, o czym warto wspomnieć, ekfrazami do obrazów Edvarda Muncha, obudowanych często historiami o źródle inspiracji do stworzenia danych prac, jak np. w przypadku $K r z y k u^{36}$, który powstał - według malarza - dzięki wrażeniu, jakie zrobił na nim zachód słońca. Inspiracje artystyczne nie wyczerpują się tu jednak na doświadczeniach.

Lars Roar Langslet, autor książki Henrik Ibsen, Edvard Munch: to genier møtes, zwrócił uwagę na fascynację Muncha twórczością Ibsena, która ujawnia się m.in. w nadawaniu cech jego własnej fizjonomii „portretowanym" postaciom ze sztuk i wierszy szwedzkiego pisarza (np. Terje Vigena). Iris Müller-Westermann twierdzi zaś, że:

Podobieństwo między Heddą Gabler, Tullą Larsen i kobietą z cyklu Śmierć Marata nie jest dziełem przypadku. Munch dostrzegał analogię między postacią Heddy Gabler, która spowodowała, że Ejlert Løvborg się zastrzelił, i Tullą Larsen, która doprowadziła jego samego do strzelenia sobie w palec ${ }^{37}$.

Jednym z utworów Ibsena, który najbardziej intrygował Muncha, był Peer Gynt. Podróż malarza do Tulli nie mogła - z uwagi m.in. na okoliczności meteorologiczne - wyglądać tak dramatycznie jak powrót Peera Gynta do Solveig, ale nic nie stało na przeszkodzie, by tak przedstawić

\footnotetext{
${ }^{34}$ The Private Journals..., s. 159.

${ }^{35}$ A. Næss, Munch..., s. 242.

${ }^{36}$ The Private Journals..., s. 64-65.

${ }^{37}$ I. Müller-Westermann, Munch by Himself, London 2005, s. 97.
} 
wydarzenia we wspomnieniach. To w końcu Brandt, nie Munch, płynie „burzliwą nocą” do jedynej kobiety, której uczucia do niego okazały się trwałe i niezmienne, nawet wówczas, gdy została przez niego porzucona. Materiały dotyczące podróży do Tulli nie są jednak tak kontrowersyjne, jak te, opisujące scenę, która rozegrała się już po przybyciu Muncha do jej domu.

W bujnie pleniących się mitach związanych z tym zdarzeniem, do których wzrostu przyczynił się przede wszystkim sam Munch, owa próba samobójcza często bywa prezentowana jako czysta inscenizacja, przedstawienie odegrane w celu oszukania Muncha. W zachowanych - wprawdzie nielicznych - materiałach źródłowych nie ma jednak nic, co by bezpośrednio wspierało takie wyjaśnienie ${ }^{38}$.

Wiemy, co zaszło według wersji, do której rozpowszechnienia przyczynił się m.in. Slavoj Žižek, przepisując do kilku swoich książek ten sam opis wydarzeń. Co natomiast pojawia się w innych pracach poświęconych Munchowi?

Munch wsiadł do łodzi. Kiedy przypłyną, była już noc. Dom był wypełniony przez ludzi, których dawno już przerósł i których się wyrzekł. Znajome postaci w tym wypełnionym świecami domu ogarnięte były szałem, wzywały lekarzy, przekazywały mu sprzeczne wersje wydarzeń: umierała z powodu morfiny; chciała się zastrzelić. Zaprowadzili go do sypialni. Była tam ułożona niczym ciało na katafalku. Świece umieszczone przy jej głowie rzucały światło na jej jasne rudo-złote włosy. Na stole zauważył znajomy pejzaż pochodzący z dni, kiedy byli ze sobą, choć do tej pory na stole leżał zawsze jeden z jej wspaniałych kapeluszy, porzucanych na koniec dnia, i miska owoców. To czy rewolwer znajdował się na stole czy w jego kieszeni, to czy był to jego rewolwer, czy jej lub też należał do jeszcze kogoś innego, pozostaje zagadką, tak samo jak szczegóły tego, co zdarzyło się za zamkniętymi drzwiami zanim padł strzał. [...] Niektóre sprawozdania podają, że ona siadła na łóżku i zaczęła się z niego śmiać. Nie wiemy jednak, które z nich tak naprawdę trzymało broń podczas szarpaniny, jaka po chwili nastąpiła, ani też czyj palec pociągnął za spust, wypuszczając kulę, która uszkodziła środkowy palec jego lewej dłoni, którą musiał zakryć lufę. Dym wypełnił pokój, krew polała się z jego dłoni, a ona nie zrobiła nic, by mu pomóc. Tak jak wtedy, gdy tańczyła Jezioro Łabędzie, przechadzała się na palcach po podłodze, potem wzięła ścierkę i zaczęła zmywać krew. Kiedy Munch odzyskał zmysły, zobaczył zatrważającą ilość krwi i kazał jej wezwać lekarza, nim wykrwawi się na śmierćc ${ }^{39}$.

Nie wiadomo, kto strzelał, ale wiadomo, że Tulla wykonywała nad omdlałym Munchem taneczne podrygi. To zastanawiające, że podobne uwagi można spotkać w książce, która w całości dotyczy norweskiego malarza i opiera się w dużej mierze na tekstach źródłowych z Muzeum Muncha. Wersja z książki Prideaux wskazuje - podobnie jak ta znana z książek

\footnotetext{
${ }^{38}$ A. Næss, Munch..., s. 241.

${ }^{39}$ S. Prideaux, Edvard Munch..., s. 222.
} 
Žižka - że do strzału doszło tego samego wieczoru, którego Tulla wezwała Muncha z powodu - faktycznego lub nie - zatrucia. W pamiętniku Munch tak opisuje spotkanie z Tullą po jej próbie samobójczej:

Och, leży tak samo, jak wcześniej - Więc nie umarła - Byli w środku pokoju, w połowie drogi - w kącie stało łóżko - tam leżała biała na poduszce - Czerwone włosy świeciły jaskrawo - Wziął ją za rękę - Jak się czujesz, zapytał cicho - Dziękuję - niezbyt dobrze - Teraz będzie ci lepiej - powiedział - Musisz spróbować być znów szczęśliwa. [...] Przyjadę zobaczyć cię znowu - za osiem dni - wtedy ty przyjedziesz do mnie do Åsgårdstrand - Wtedy zrobię wszystko, co w mojej mocy, by wszystko naprawić. [...] Szedł drogą do Drøbak $^{40}$.

Po spokojnej rozmowie padają pewne obietnice, a Brandt rusza w drogę powrotną do domu. Nie ma w tym miejscu mowy o rewolwerze, nie wspominając już o jakimkolwiek teatralnym sztafażu. Od relacji Muncha ważniejsze są jednak w tym wypadku daty, a karta szpitalna jasno wskazuje na to, że malarz przebywał w nim dopiero we wrześniu. 12 września, po przybyciu do szpitala, wykonano zdjęcie rentgenowskie jego dłoni, która została zoperowana kolejnego dnia. Oczywiste jest zatem, że próbę samobójczą Tulli i wystrzał z rewolweru dzieli szereg dni. W karcie Muncha można znaleźć, poza datami, także kolejną wersję wydarzeń z feralnego wieczoru, wymyśloną zapewne celem pomniejszenia rozmiarów skandalu:

Pac[jent] wczoraj wieczorem obracał w rękach rewolwer, który nagle wystrzelił, kula przeszyła środkowy palec lewej ręki. St[atus] Pr[esens]: Kula przeszła przez pierwszy paliczek lewego palca środkowego od strony kciuka i wyszła od strony łokciowej, stamtąd weszła w palec serdeczny. W otworze po kuli widać odłamki kości ${ }^{41}$.

Atle Næss, świadom pułapek czyhających na badacza życiorysu Muncha, idzie tropem wytyczonym przez materiał źródłowy. Kiedy jednak przychodzi do opisu momentu oddania strzału z rewolweru, również on jest, jak się zdaje, bezsilny wobec potencjału literackiego tej sceny.

Nie było nic dziwnego ani niezwykłego w fakcie, że Munch miał w domku rewolwer. [...] Gdy powrócił do domku w to nieszczęsne czwartkowe popołudnie, był w stanie psychicznego i fizycznego wyczerpania, wywołanego konfrontacją z tym co teraz, zaledwie po jednej dobie przebywania razem, wydawało się sytuacją bez możliwości ucieczki: „Nie mogłem jej po prostu przegonić - ani też zabić - Nie mogłem też z nią żyć”.

Tulla szykuje posiłek, ale Munch nie chce jeść. Zamiast tego zaczyna pić koniak. Zapada ciemność, godziny płyną. Tulla stoi w drzwiach za jego plecami. Odzywają się do siebie mało lub wcale.

${ }^{40}$ The Private Journals..., s. 162, 164-165.

${ }^{41}$ Karta choroby Edvarda Muncha z Rigshospital, cyt. za: A. Næss, Munch..., s. 246. 
W jakimś momencie Munch sięga po broń, która najprawdopodobniej po prostu, ot, tak sobie leży w pokoju: „Nagle trzymałem rewolwer w dłoni skąd go wziąłem - czego chciałem - nie wiem -". Istnieje wiele wersji dalszych wydarzeń. Całkiem pewne jest tylko to, że w małym pomieszczeniu rozległ się huk wystrzału. Kula trafiła Muncha w palec środkowy lewej dłoni, przeszła na wylot, pozostawiając wielką krwawiącą ranę ${ }^{42}$.

Do postrzału nie doszło w Larkollen, ale w Åsgårdstrand, w domu malarza. Tu kończą się fakty, a zaczynają domysły i czysta beletryzacja. Jeden z zapisków Muncha przynosi dość przewrotne rozwiązanie impasu związanego z wystrzałem:

Ta wola działa niezauważalnie - instynktownie - rządzi podświadomym mechanizmem - sprawia, że krew krąży - czyżby się zbuntowała? - Czy ta druga wola zdawała sobie sprawę, że z tego nie ma już wyjścia, że jeśli ona jest taka sama - jak dawniej - To pozostała mi śmierć - że nie mogę dłużej ${ }^{43}$.

Atle Næss poddaje się ostatecznie sile wypowiedzi Muncha, jego teorii o „krzyku woli”, i buduje paralelę między postrzałem w dłoń a samookaleczeniem się van Gogha. Jakże odmiennie prezentuje się opis sceny strzału z książki Eli Greve:

W tej gorzkiej godzinie pożegnania dwojga ludzi, którzy przez cztery lata na próżno poszukiwali wspólnoty, ona zrozpaczona sięgnęła po rewolwer. On, aby ją ochronić i zapobiec nieszczęściu, nakrył jej rękę swoją, lecz strzał padł, nieodwracalnie kalecząc dłoń, która trzyma paletę ${ }^{44}$.

W nieskończoność można byłoby mnożyć przykłady odmiennych wersji wypadków z wieczoru, gdy Munch stracił część palca. Niektóre opisy dają Tulli rolę jedynie bierną, jak np. poczyniony przez Rolfa Söderberga: „Zrywając teatralnie ze swoją narzeczoną, aktorką Tullą Larsen, Munch złapał za pistolet i odstrzelił sobie połowę drugiego palca [sic!] lewej dłoni”45. Nieścisłości - od drobnych do bardzo poważnych - pojawiają się na kartach większości prac, których bohaterem stał się rewolwer. Jest, jak się zdaje, coś niewłaściwego w „złożeniu broni” i przyznaniu się do niewiedzy, a w rzeczy samej - wobec tak daleko posuniętej mityzacji wydarzenia, wobec tego, iż jedynymi świadkami byli jego uczestnicy, których wersje są sprzeczne - właśnie to pozostaje zrobić. Kiedy jednak fakty się wyczerpują,

${ }^{42}$ Tamże, s. 245 .

${ }^{43}$ Tamże.

${ }^{44}$ E. Greve, Edvard Munch. Liv og verk i lys av tresnittene, s. 23, cyt. za: A. Næss, Munch..., s. 245.

${ }^{45}$ R. Söderberg, Edvard Munch, August Strindberg: fotografi som verktyg och experiment, Sztokholm 1989, s. 50. 
zjawia się wyobraźnia. Kiedy Munch przestaje wystarczać, na scenę wchodzi Brandt, a Brandt ,jest obrazem”46. Aleksander Świętochowski napisał, że „rewolwer, nóż, sztylet są instancjami, do których najczęściej odwołujemy się w sporach, i narzędziami, któremi najchętniej piszemy naszą historię"47. Munch napisał swój autobiograficzny poemat tym rewolwerem, który miał przy swojej skroni bohater Requiem aeternam i który, niczym Makryna, wędruje dalej niosąc złe wieści.

\section{Whose revolver is it? A story of an excerpt from Edvard Munch's journal}

\section{Summary}

The purpose of this article is to identify problems faced by literary scholars, studying biographies and works of artists in the late nineteenth and early 2oth century. Attempts to reproduce a comprehensive biography of the most famous members of the European bohemia are often hindered by legends that had overgrown the most ordinary events of their lives. The result of rumors, spread for over the years, is a version of events, which no one verifies anymore, because it is repeated by unquestionable authorities in culture.

The most mythopoetic events were - in the era of the fin de siècle - the tragic ones, which have occurred behind closed doors and without witnesses, because the atmosphere of mystery was even more inspiring for imagination. It resulted in scenarios that were often very far from the truth but sometimes much more interesting than reality.

Shots from a revolver, which went off on Tiflis, killing Dagny Juel and Władysław Emeryk, and then another one that left wounds on the body and soul of Edvard Munch, became heroes of the collective imagination. Especially in the latter case, on which the analysis of this paper focuses, fantasies sometimes took (and still take) priority over common sense.

${ }^{46}$ The Private Journals..., s. 154.

${ }^{47}$ M. Brykalska, Aleksander Świętochowski, Warszawa 1987, t. 2, s. 184. 